\title{
がん患者における麻薬性鎮痛薬の薬物動態及び臨床効果の個人差要因
}

\author{
内藤隆 文, ${ }^{*} 川$ 上 純一
}

\section{Interindividual Variation of Pharmacokinetic Disposition of and Clinical Responses to Opioid Analgesics in Cancer Pain Patients}

\author{
Takafumi Naito* and Junichi Kawakami \\ Department of Hospital Pharmacy, Hamamatsu University School of Medicine; \\ 1-20-1 Handayama, Higashi-ku, Hamamatsu 431-3192, Japan.
}

(Received September 26, 2014)

\begin{abstract}
Use of prescription opioids for cancer pain according to the World Health Organization analgesic ladder has been accepted in Japan. Although oxycodone and fentanyl are commonly used as first-line analgesics, a few clinical reports have been published on interindividual variations in their pharmacokinetics and clinical responses in cancer patients. (1) Some factors relating to CYP2D6, CYP3A, ATP-binding cassette sub-family B member 1 (ABCB1), and opioid receptor mu 1 (OPRM1) involve oxycodone pharmacokinetics and sensitivity in humans. The relations between their genetic variations and clinical responses to oxycodone are being revealed in limited groups. In our study, the impact of genetic variants and pharmacokinetics on clinical responses to oxycodone were evaluated in Japanese populations. (2) Opioid switching improves the opioid tolerance related to the balance between analgesia and adverse effects. Some patients have difficulty in obtaining better opioid tolerance in recommended conversion ratios. The activities of CYP3A, $\mathrm{ABCB} 1$, and OPRM1 contribute to the interindividual variations in clinical responses to fentanyl in cancer patients. However, the variations in opioid switching remain to be clarified in clinical settings. In our study, genetic factors related to interindividual variations in clinical responses in opioid switching to fentanyl were revealed in Japanese populations. In this symposium review, the possibility of approaches to personalized palliative care using opioids based on genetic variants of CYP2D6, CYP3A5, ABCB1, and OPRM1 is discussed.
\end{abstract}

Key words_ cancer pain; individualized therapy; opioid; analgesics; pharmacokinetics

\section{1. はじめに}

近年，日本でも世界保健機関や欧州緩和医療学会 の除痛ラダーに基づくがん性疼痛に対するオピオイ ドの使用が普及してきている。しかし，日本におけ るオピオイドの使用率は, 他の先進国に比べて低 い. ${ }^{1,2)}$ 緩和医療へのオピオイドの導入が進んでいる 欧州諸国や米国においても，医療用麻薬であるモル ヒネ, オキシコドン, フェンタニル及びメサドンの 鎮痛効果，有害作用及び耐性形成の個別化に関する エビデンスはそしく，現状では，国毎のガイドライ ンに基づいた画一的な除痛療法が実施されてい る. ${ }^{3)}$

浜松医科大学医学部附属病院薬剂部（干431-3192 浜松 市東区半田山一丁目 20 番 1 号)

*e-mail: naitou@ hama-med.ac.jp

本総説は, 日本薬学会第 134 年会シンポジウムS27 で 発表した内容を中心に記述したものである.
オキシコドンやフェンタニルについては, がん性 疼痛に対するベースライン鎮痛薬として導入されな がらも, がん患者における血中動態, 鎮痛効果及び 有害作用の個人差要因に関する臨床デー夕は乏し い. オキシコドンの場合には，CYP2D6, CYP3A 及び $\mathrm{P}$ 糖タンパク質 (ATP-binding cassette sub-family B member 1; ABCB1) が薬物代謝や体内分布に, $\mu$ オピオイド受容体 (opioid receptor, mu 1; OPRM1）がオピオイド感受性に関与する. ${ }^{4-6)}$ フエ ンタニルの場合にも，オキシコドンと同様の CYP3A, ABCB1 及び OPRM1 が関与する. ${ }^{7-9)}$ 現 在, それらの遺伝的多様性とオキシコドン及びフェ ンタニルの臨床効果との関連性が解明されつつあ る. 10-16) しかし, 実臨床で想定される経口オピオイ ドからフェンタニル貼付剤への切り替えに関して, 有害作用や鎮痛効果の個人差要因を評価した報告は ほとんどない。 


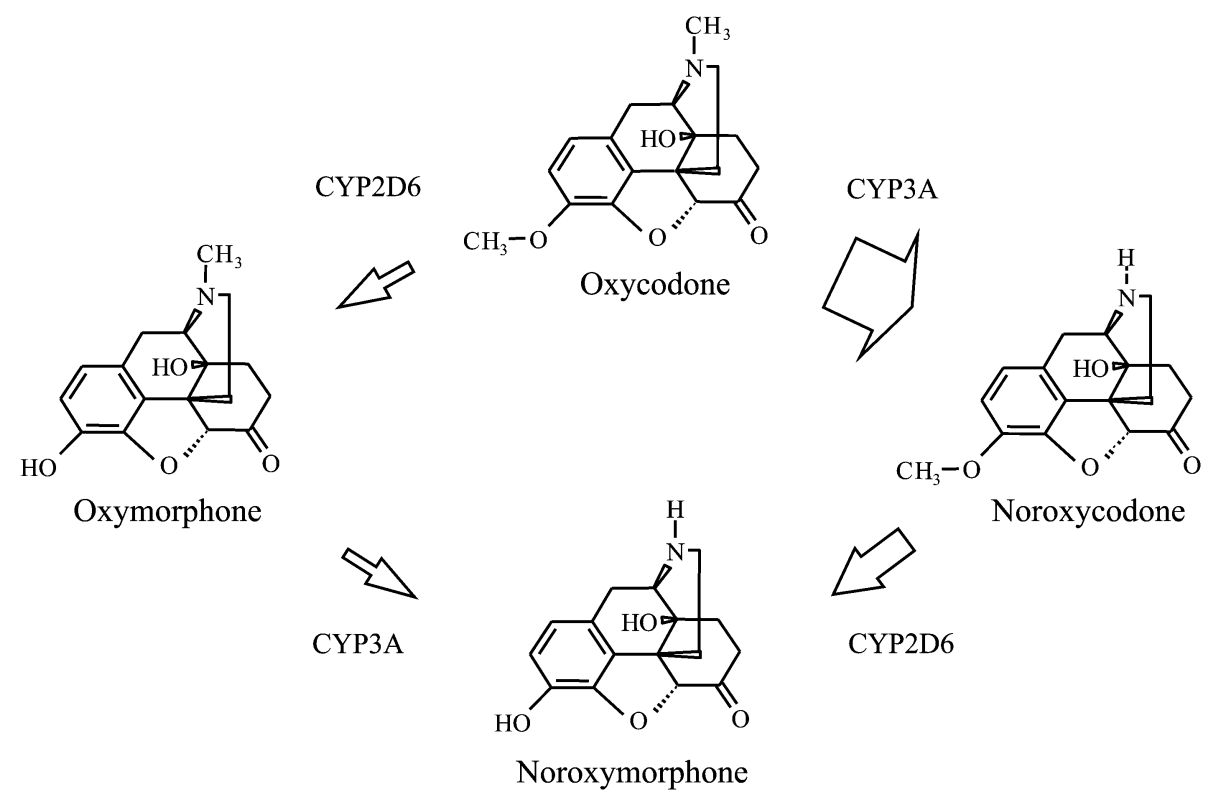

Fig. 1. Metabolic Pathway of Oxycodone in Humans

上記の背景を踏まえて, 筆者らは薬物動態学及び 薬力学解析の 2 つの視点から, オキシコドンの体内 動態及び臨床効果の個人差, フェンタニルへの切り 替えにおけるフェンタニルの体内動態及び臨床効果 の個人差について解析を行つた．本総説では，がん 患者におけるオキシコドン及びフェンタニルの個人 差要因に関して，得られた知見の概要を示す.

2. オキシコドンの血中動態及び臨床効果の個人 差要因 ${ }^{17)}$

オキシコドンは CYP2D6 により鎮痛活性の高い オキシモルフォンと CYP3A により鎮痛活性の低い ノルオキシコドンに代謝される（Fig. 1)。最近, 健常人において，オキシコドンの鎮痛作用に対する CYP2D6 の遺伝子変異とオキシモルフォンの関与

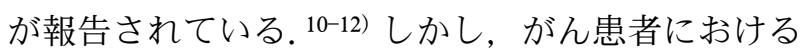
オキシコドンの有害作用や耐性形成に及ぼす薬物代 謝酵素やオピオイド受容体の遺伝子変異の影響は明 らかではない. 本研究では, オキシコドン, オキシ モルフォン及びノルオキシコドンの薬物動態解析に 基づいて，がん患者におけるオキシコドンの血中動 態, 有害作用及び増量速度に及ぼす CYP2D6, CYP3A5, ABCB1 及び OPRM1 の遺伝子変異の影 響について検討した。

対象は浜松医科大学病院において, がん性疼痛に 対し，オキシコドンの服用を開始した 62 名の患者 とした。対象患者における CYP2D6, CYP3A5,
$\mathrm{ABCB} 1$ 及び OPRM1 の遺伝子型を判定した。オキ シコドンによる有害作用の発現率, オキシコドンの 耐性形成の指標として，増量速度を表す opioid escalation index (OEI) を算出し, ${ }^{18)}$ オキシコドンと その代謝物の血中動態との関係を解析した.

血漿中オキシコドン濃度は, CYP2D6, CYP3A5 及び ABCB1 の遺伝子変異の影響を受けなかった. 血漿中オキシモルフォン濃度は, CYP2D6 の extensive metabolizer (EM) 群に比べ, intermediate metabolizer（IM）群では有意に低值を示した（Fig. 2). オキシモルフォンとオキシコドンの濃度比（才 キシモルフォン/オキシコドン）とCYP2D6 との関 係では, EM 群に比べ, IM 群では有意に低值を示 した. 血漿中ノルオキシコドン濃度は, $C Y P 3 A 5^{*} 3 /$ *3 群で* $1 /{ }^{*} 1+{ }^{*} 1 /{ }^{*} 3$ 群と比較し, 有意に低值を示 した（Fig. 3).また，ノルオキシコドンとオキシ コドンの濃度比（ノルオキシコドン/オキシコドン） は, $C Y P 3 A 5^{*} 3 /{ }^{*} 3$ 群で* $1 /{ }^{*} 1+{ }^{*} 1 /{ }^{*} 3$ 群と比較し, 有意に低值を示した。

オキシコドンの有害作用の発現率について, CYP2D6, CYP3A5, ABCB1 及び OPRM1 の遺伝子 変異の影響は認められなかつた。 また, OEI では $C Y P 3 A 5^{*} 3 / * 3$ 群で* $1 /{ }^{*} 1+* 1 / * 3$ 群と比べ有意に高 值を示した（Fig. 4)。一方で，OEIに及ぼす CYP2D6, ABCB1 及び OPRM1 の遺伝子変異の影 響は認められなかった。また，OEI は血漿中ノル 
(A)

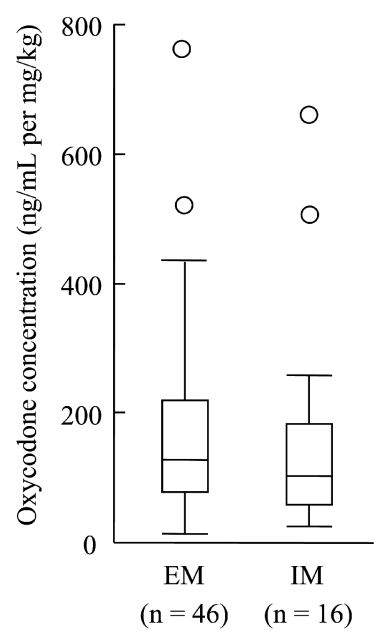

(B)

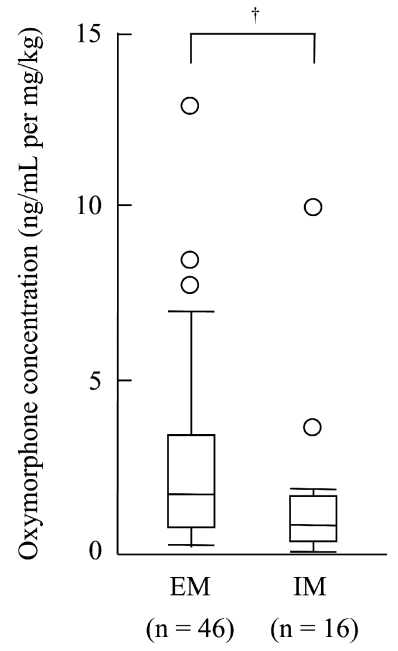

(C)

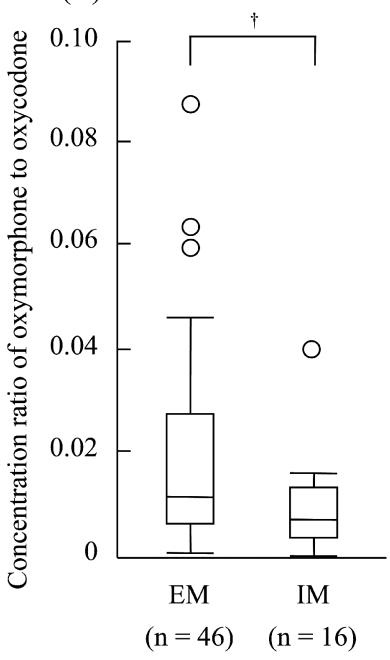

Fig. 2. Influence of CYP2D6 Phenotype on Predose Plasma Concentration of Oxycodone and Its Demethylates in Cancer Patients Extensive metabolizer, EM $\left(C Y P 2 D 6^{*} 1 /{ }^{*} 1,{ }^{*} 1 / *^{*} 2,{ }^{*} 1 / *_{5},{ }^{*} 1 /{ }^{*} 10,{ }^{*} 2 /{ }^{*} 2,{ }^{*} 2 /{ }^{*} 5\right.$, and $\left.{ }^{*} 2 /{ }^{*} 10\right)$; intermediate metabolizer, IM $\left(C Y P 2 D 6{ }^{*} 5 /{ }^{*} 10\right.$ and $\left.{ }^{*} 10 /{ }^{*} 10\right)$. Box plots represent the median, 25th, and 75th percentiles. The whiskers indicate the range and extend within 1.5 times the length of the inner quartiles. Statistical analysis was performed using the Mann-Whitney $U$ test. ${ }^{\dagger} p<0.05$.

(A)

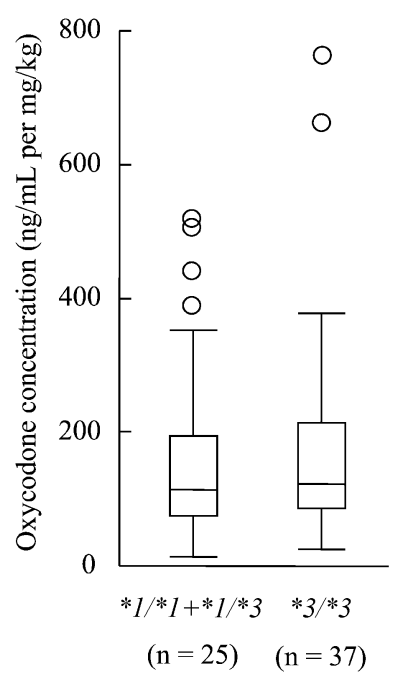

(B)

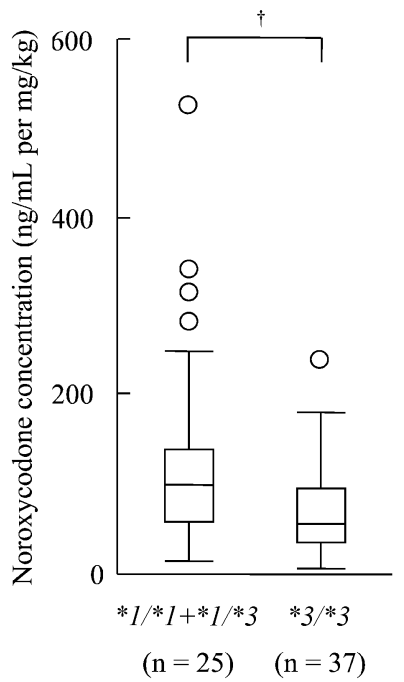

(C)

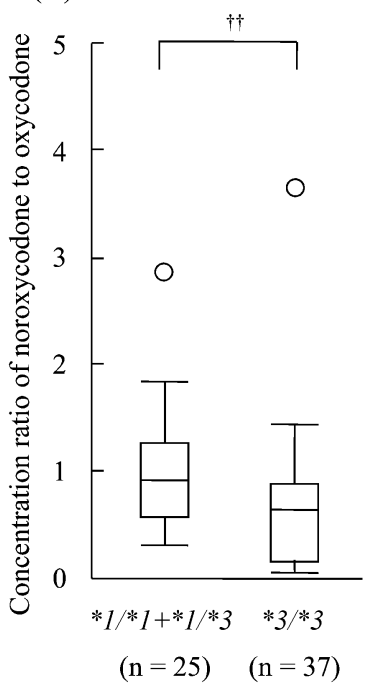

Fig. 3. Influence of $C Y P 3 A 5^{*} 3$ on Predose Plasma Concentration of Oxycodone and Its Demethylates in Cancer Patients Box plots represent the median, 25th, and 75th percentiles. The whiskers indicate the range and extend within 1.5 times the length of the inner quartiles. Statistical analysis was performed using the Mann-Whitney $U$ test. ${ }^{*} p<0.05,{ }^{\sharp \dagger} p<0.01$.

オキシコドン濃度と逆相関を示したが，血漿中オキ シコドン及びオキシモルフォン濃度との関係は認め られなかった。

以上より, CYP2D6 と CYP3A5 の遺伝子変異 は，オキシコドンの血中動態にほとんど影響を及ぼ さないが，オキシコドンの代謝経路と代謝物の血中 動態に影響を及ぼすことが示された。がん患者にお けるオキシコドンの増量速度に影響を及ぼす要因と して，CYP3A5*3 が挙げられ，CYP3A5 を介さな
い代謝経路への依存度が，オキシコドンの耐性形成 に影響を及ぼす可能性が示された。

\section{3. フェンタニル貼付剤への切り替え後の血中動} 態の個人差要因 ${ }^{19}$

フェンタニルは選択的 $\mu$ オピオイド受容体作動 性であり，モルヒネと比べて眠気や嘔気，便秘と いつた有害作用の発現頻度は少ないとされてい る. ${ }^{20,21)}$ このため, オピオイドを使用している患者 において，有害作用の軽減や投与経路の変更を目的 

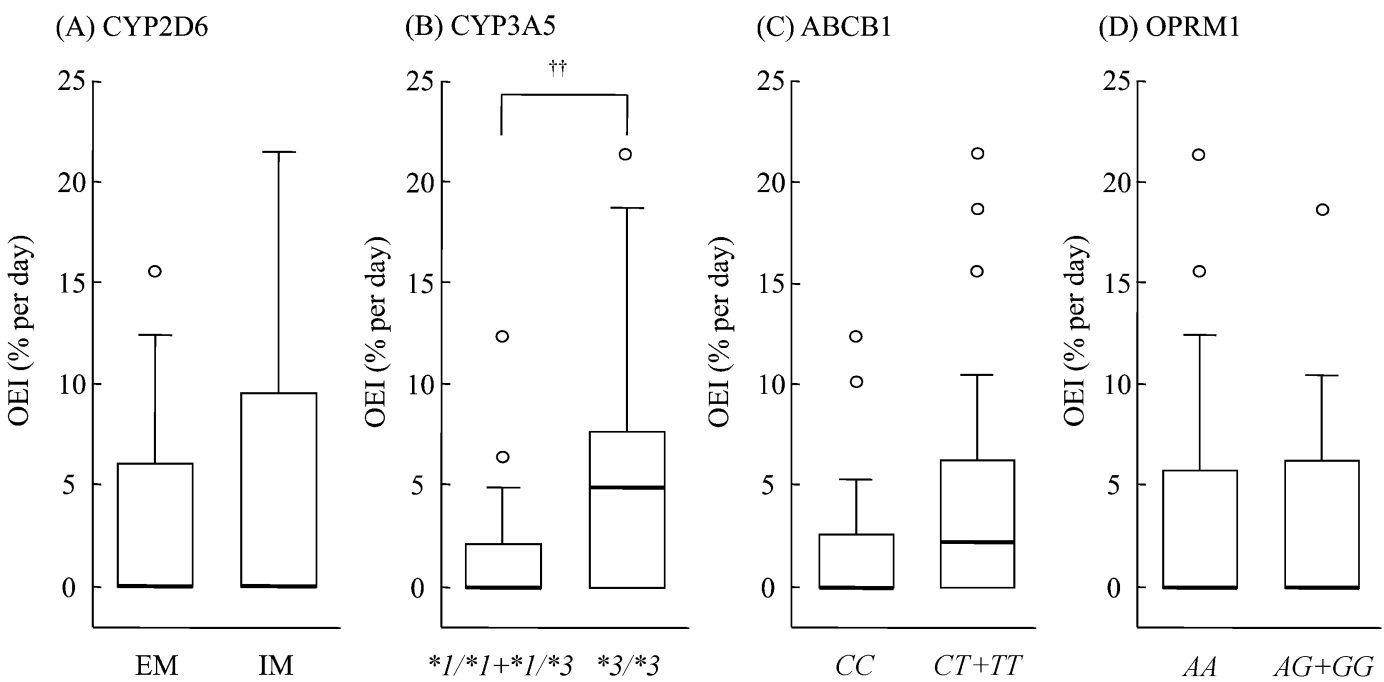

Fig. 4. Influences of CYP2D6 Phenotype (A), CYP3A5*3 (B), ATP-binding Cassette Sub-family B Member 1 (ABCB1) C3435T (C), and Opioid Receptor, mu 1 (OPRMI) A118G (D) on the Opioid Escalation Index (OEI) in Cancer Pain Patients

Box plots represent the median (bold line), 25th, and 75th percentiles. The whiskers indicate the range and extend within 1.5 times the length of the inner quartiles. Statistical analysis was performed using the Mann-Whitney $U$ test. ${ }^{\star \star} p<0.01$.

に, フェンタニル貼付剤への切り替えが行われ る. ${ }^{22)}$ しかし，推奨投与量換算比に沿った切り替え を行つた場合でも，疼痛管理が不良になる患者や眠 気, せん妄等の有害作用を強く出現する患者も存在 する，そこで，本研究ではフェンタニル貼付剤への 切り替え実施後のフェンタニルの血中動態に及ぼす CYP3A5 とABCB1 の遺伝子変異の影響について評 価した.

対象は浜松医科大学病院において, 有害作用の軽 減や疼痛管理の改善を目的に, 他の経口オピオイド (モルヒネ，オキシコドン）からフェンタニル貼付 剂に切り替えを実施した 60 名のがん患者とした. 対象患者における CYP3A5 と ABCB1 の遺伝子型 を判定した。 フェンタニルの血漿中濃度における定 常状態到達時間を考慮し, 貼付剤に切り替えてから 192 時間後の血漿中フェンタニル濃度を評価した.

血漿中フェンタニル濃度には，体重補正した理論 放出速度との間に有意な相関が認められたものの, 大きな個人差が存在した。さらに実測のフェンタニ ル吸収速度と血漿中フェンタニル濃度との関係につ いても同様の個人差が認められた。CYP3A5*3/*3 群では， ${ }^{*} 1 /{ }^{*} 1$ 群及び* $1 /{ }^{*} 3$ 群と比較して，それぞ れ，有意に血漿中フェンタニル濃度が高值を示した (Fig. 5). CYP $3 A 5^{*} 3 /{ }^{*} 3$ 群では, ${ }^{*} 1$ 保持 $\left({ }^{*} 1 /{ }^{*} 1+\right.$ * $1 / * 3)$ 群と比較し, 血漿中フェンタニル濃度が約 2 倍高值を示した。また, CYP $3 A 5^{*} 3 / * 3$ 群におい

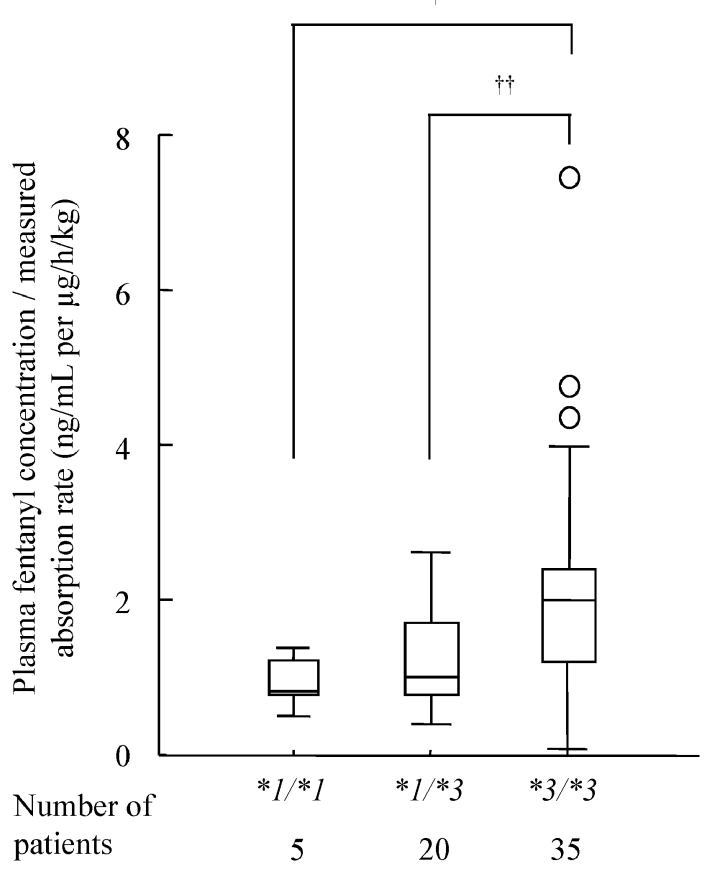

Fig. 5. Influence of $C Y P 3 A 5^{*} 3$ on Fentanyl Pharmacokinetics in Cancer Patients

Box plots represent the median, 25th, and 75th percentiles. The whiskers indicate the range and extend within 1.5 times the length of the inner quartiles. Statistical analysis was performed using Kruskal-Wallis and MannWhitney $U$ tests. ${ }^{*} p<0.05,{ }^{\sharp "} p<0.01$.

て，血漿中フェンタニル濃度のばらつきは, ${ }^{*} 1 /{ }^{*} 1$ 群と* $1 /{ }^{*} 3$ 群のそれぞれと比較して大きかった。一 方，血漿中フェンタニル濃度に及ぼす $\mathrm{ABCB} 1$ の遺 伝子多型（C1236T, G2677A/T,C3435T）の影響は 
(A) $C 1236 T$

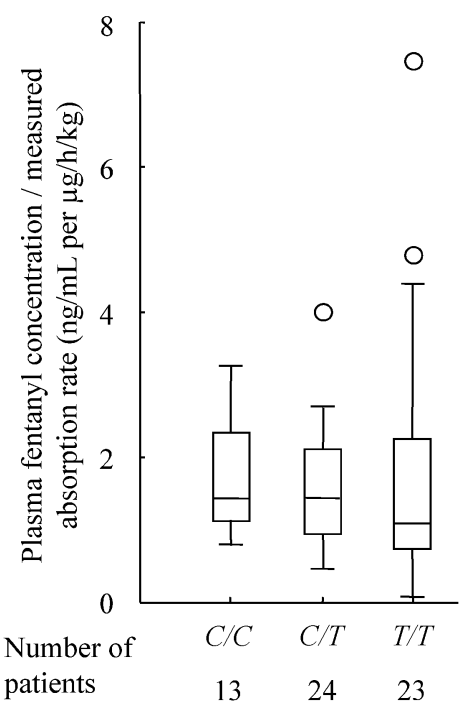

(B) $G 2677 A / T$

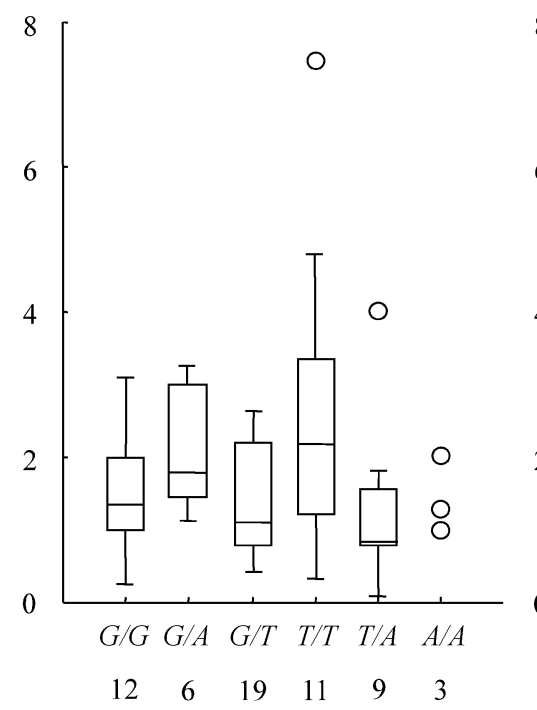

(C) $C 3435 T$

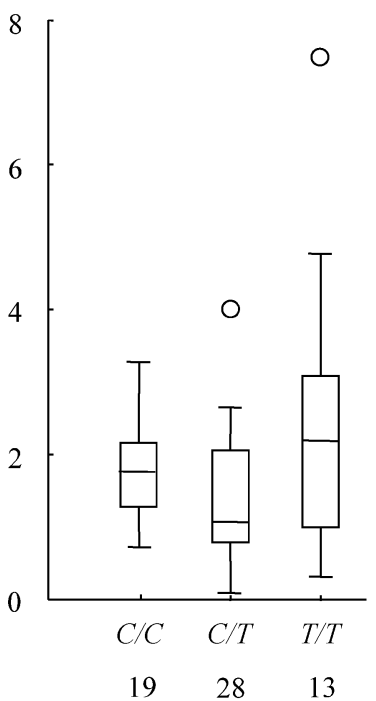

Fig. 6. Influence of ATP-binding Cassette Sub-family B Member 1 (ABCB1) Genetic Variants, C1236T (A), G2677A/T (B) and C3435T (C) on the Plasma Disposition of Fentanyl in Cancer Patients

Box plots represent the median, 25th, and 75th percentiles. The whiskers indicate the range and extend within 1.5 times the length of the inner quartiles. Statistical analysis was performed using Kruskal-Wallis test.

認められなかった（Fig. 6).

以上より，フェンタニル貼付剤への切り替えを実 施したがん患者において，CYP3A5*3 は血漿中 フェンタニルの濃度を上昇させる要因であることが 示された.

4. フェンタニル貼付剤への切り替え後の臨床効 果の個人差要因 ${ }^{19)}$

次にフェンタニル貼付剂への切り替え実施後にお ける有害作用の発現及び鎮痛効果に及ぼす CYP3A5 と ABCB1 の遺伝子変異の影響を明らかに するために，フェンタニルの血中動態を含めた臨床 効果を規定する要因について評価を行った.

対象は有害作用の軽減や疼痛管理の改善を目的 に，他の経ロオピオイドからフェンタニル貼付剂に 切り替えを実施した前章と同一の 60 名の患者とし た。 フェンタニルの定常状態到達後（192 時間後） の血漿中濃度とともに，その期間における有害作用 の発現の有無と体動時痛以外の疼痛に対するレス キュー投与の有無を評価した。

フェンタニル貼付剂への切り替え時の有害作用と 鎮痛効果に及ぼす CYP3A5 と ABCB1 の遺伝子変 異の影響について, Table 1 に示す。フェンタニル 貼付剂切り替え後の有害作用に関しては, 多変量解 析において, CYP $3 A 5^{*} 3 /{ }^{*} 3$ 群では, ${ }^{*} 1 /{ }^{*} 1+{ }^{*} 1 /{ }^{*} 3$ 群と比較し，中枢性有害作用の発現リスクが 3.5 倍
有意に高かつた。 $A B C B 12677 G$ アレル非保持 $(2677 T T+T A+A A)$ 群では $2677 G$ アレル保持 $(2677 G G+G A+G T)$ 群と比較して, 嘔吐・嘔気 の発現リスクが 3.1 倍高い傾向がみられた. $A B C B 12677 G$ アレル非保持群では $2677 G$ アレル保 持群と比較して，便秘の発現リスクが 2.3 倍高い傾 向がみられた. フェンタニル貼付剤切り替え後の鎮 痛効果に関しては，ABCB1 1236C アレル非保持 (1236TT) 群では $1236 C$ アレル保持 $(1236 C C+C T)$ 群と比較して，レスキュー投与頻度が 0.17 倍と有 意に減少した。一方，レスキュー投与が必要であっ た患者と必要でなかった患者の両群間における血漿 中フェンタニル濃度には違いが認められなかった。

以上より, $C Y P 3 A 5^{*} 3$ がフェンタニルの中枢性 有害作用発現リスク，ABCB1 C1236Tがフェンタ ニルの鎮痛効果を規定する要因であることが示され た.また，これらの遺伝子多型の解析は，フェン夕 ニル貼付剤への切り替え実施後におけるフェンタニ ルの臨床効果の予測に有用であることが考えられた.

\section{5. おわりに}

本研究により得られた知見について総括する.

オキシコドン服用患者において，CYP $A A 5^{*} 3$ は オキシコドンの代謝経路と代謝物の血中動態に影響 を及ぼし，CYP $3 A 5^{*} 3$ により規定されるノルオキ シコドンの血中動態は, オキシコドンの増量速度に 
Table 1. Influence of CYP3A5 and ATP-binding Cassette Sub-family B Member 1 (ABCB1) Genetic Variants on Incidence of Adverse Effects and Rescue Medication in Cancer Patients Switching to Fentanyl Transdermal System

\begin{tabular}{|c|c|c|c|c|c|}
\hline \multirow{2}{*}{ Genotypes } & & \multicolumn{3}{|c|}{ Adverse effects } & \multirow{2}{*}{$\begin{array}{c}\text { Rescue } \\
\text { medication, } \\
n\end{array}$} \\
\hline & & $\begin{array}{l}\text { Central adverse } \\
\quad \text { effects, } n\end{array}$ & $\begin{array}{c}\text { Constipation, } \\
n\end{array}$ & $\begin{array}{l}\text { Nausea or } \\
\text { vomiting, } n\end{array}$ & \\
\hline \multirow[t]{2}{*}{$C Y P 3 A 5^{*} 3$} & ${ }^{*} 1 /{ }^{*} 1+{ }^{*} 1 /{ }^{*} 3 \quad(n=25)$ & 10 & 10 & 9 & 11 \\
\hline & ${ }^{*} 3 /{ }^{*} 3 \quad(n=35)$ & 23 & 19 & 10 & 14 \\
\hline \multirow[t]{2}{*}{$A B C B 1 C 1236 T$} & $C C+C T(n=37)$ & 22 & 18 & 12 & 19 \\
\hline & $T T(n=23)$ & 11 & 11 & 7 & 6 \\
\hline \multirow[t]{2}{*}{$A B C B 1 G 2677 A / T$} & $G G+G A+G T(n=37)$ & 20 & 16 & 9 & 17 \\
\hline & $T T+T A+A A \quad(n=23)$ & 13 & 13 & 10 & 8 \\
\hline \multirow[t]{2}{*}{$A B C B 1 C 3435 T$} & $C C+C T(n=47)$ & 26 & 23 & 14 & 20 \\
\hline & $T T(n=13)$ & 7 & 6 & 5 & 5 \\
\hline
\end{tabular}

影響を及ぼすことを明らかにした。

フェンタニルの貼付患者では，その血中動態の変 動因子として, $C Y P 3 A 5^{*} 3$ が示された。また, フェンタニルの貼付剤への切り替え時の中枢性有害 作用の発現のリスク因子としても，CYP $3 A 5^{*} 3$ が 示された. さらにレスキュー投与の誘発因子として, $A B C B 1$ 1236C アレル保持が示された.

以上, 本研究成果はがん患者におけるオピオイド の体内動態, 有害作用及び而性形成に関する個人差 の予測性を示すものである.さらに医療現場から創 出されたこれらのエビデンスは, 緩和医療における 鎮痛薬の適正使用や個別化薬物療法の構築に大きく 貢献するものである.

謝辞本研究を遂行するにあたり，ご協力を頂 きました共同研究者である静岡県立大学大学院薬学 研究科臨床薬剂学講座の賀川義之教授, 浜松医科大 学医学部附属病院腫瘍センターの大西一功教授に感 謝の意を表します。

利益相反＼cjkstart開示すべき利益相反はない.

\section{REFERENCES}

1) Otsuka K., Yasuhara H., J. Pain Palliat. Care Pharmacother., 21, 37-42 (2007).

2) Takeda F., Jpn. J. Clin. Med., 59, 1663-1668 (2001).

3) Yamaguchi T., Shima Y., Morita T., Hosoya M., Matoba M., Japanese Society of Palliative Medicine, Jpn. J. Clin. Oncol., 43, 896-909
(2013) .

4) Lalovic B., Phillips B., Risler L. L., Howald W., Shen D. D., Drug Metab. Dispos., 32, 447-454 (2004).

5) Hassan H. E., Myers A. L., Lee I. J., Coop A., Eddington N. D., J. Pharm. Sci., 96, 2494-2506 (2007).

6) Holtman J. R. Jr., Wala E. P., Pharmacol. Biochem. Behav., 83, 100-108 (2006).

7) Labroo R. B., Paine M. F., Thummel K. E., Kharasch E. D., Drug Metab. Dispos., 25, 1072-1080 (1997).

8) Henthorn T. K., Liu Y., Mahapatro M., Ng K. Y., J. Pharmacol. Exp. Ther., 289, 10841089 (1999).

9) Oertel B. G., Preibisch C., Wallenhorst T., Hummel T., Clin. Pharmacol. Ther., 83, 577588 (2008).

10) Zwisler S. T., Enggaard T. P., Mikkelsen S., Brosen K., Sindrup S. H., Acta Anaesthesiol. Scand., 54, 232-240 (2010).

11) Samer C. F., Daali Y., Wagner M., Hopfgartner G., Eap C. B., Rebsamen M. C., Rossier M. F., Hochstrasser D., Dayer P., Desmeules J. A., Br. J. Pharmacol., 160, 919-930 (2010).

12) Andreassen T. N., Eftedal I., Klepstad P., Davies A., Bjordal K., Lundström S., Kaasa S., Dale O., Eur. J. Clin. Pharmacol., 68, 55-64 (2012).

13) Zwisler S. T., Enggaard T. P., Noehr-Jensen L., Mikkelsen S., Verstuyft C., Becquemont L., Sindrup S. H., Brosen K., Fundam. Clin. Pharmacol., 24, 517-524 (2010). 
14) Klepstad P., Rakvåg T. T., Kaasa S., Holthe M., Dale O., Borchgrevink P. C., Baar C., Vikan T., Krokan H. E., Skorpen F., Acta Anaesthesiol. Scand., 48, 1232-1239 (2004).

15) Park H. J., Shinn H. K., Ryu S. H., Lee H. S., Park C. S., Kang J. H., Clin. Pharmacol. Ther., 81, 539-546 (2007).

16) Zhang W., Yuan J. J., Kan Q. C., Zhang L. R., Chang Y. Z., Wang Z. Y., Li Z. S., Eur. J. Anaesthesiol., 28, 245-250 (2011).

17) Naito T., Takashina Y., Yamamoto K., Tashiro M., Ohnishi K., Kagawa Y., Kawakami J., J. Clin. Pharmacol., 51, 1529-1538 (2011).

18) Mercadante S., Fulfaro F., Casuccio A., Bar- resi L., J. Pain Symptom. Manage., 18, 347352 (1999).

19) Takashina Y., Naito T., Mino Y., Yagi T., Ohnishi K., Kawakami J., Drug Metab. Pharmacokinet., 27, 414-421 (2012).

20) McNamara P., Palliative Med., 16, 425-434 (2002).

21) Morita T., Takigawa C., Onishi H., Tajima T., Tani K., Matsubara T., Miyoshi I., Ikenaga M., Akechi T., Uchitomi Y., Japan Pain, Rehabilitation, Palliative Medicine, and Psycho-Oncology (PRPP) Study Group, J. Pain Symptom. Manag., 30, 96-103 (2005).

22) Mercadante S., Bruera E., Cancer Treat. Rev., 32, 304-315 (2006). 